\begin{abstract}
Iranica
Abstracta Iranica Revue bibliographique pour le domaine irano-aryen

Volume 32-33 | 2013

Comptes rendus des publications de 2009-2010
\end{abstract}

\title{
Rika Gyselen. Un trésor monétaire sassanide du VIe siècle
}

Nikolaus Schindel

\section{(2) OpenEdition \\ 12 Journals}

\section{Electronic version}

URL: http://journals.openedition.org/abstractairanica/40508

DOI: 10.4000/abstractairanica.40508

ISSN: 1961-960X

Publisher:

CNRS (UMR 7528 Mondes iraniens et indiens), Éditions de l'IFRI

\section{Printed version}

Date of publication: 1 December 2013

ISSN: 0240-8910

\section{Electronic reference}

Nikolaus Schindel, « Rika Gyselen. Un trésor monétaire sassanide du Vle siècle », Abstracta Iranica [Online], Volume 32-33 | 2013, document 166, Online since 01 July 2016, connection on 03 October 2020. URL : http://journals.openedition.org/abstractairanica/40508 ; DOI : https://doi.org/10.4000/ abstractairanica. 40508

This text was automatically generated on 3 October 2020.

Tous droits réservés 


\title{
Rika Gyselen. Un trésor monétaire sassanide du VIe siècle
}

\author{
Nikolaus Schindel
}

\section{REFERENCES}

Rika Gyselen. «Un trésor monétaire sassanide du VIe siècle ». Res Orientales XIX, Sources for the History of Sasanian and Post-Sasanian Iran. Bures-sur-Yvette / Leuven, GECMO / Peeters Press, 2010, p. 135-147.

1 The author presents a short overview of a hoard of 1049 Sasanian drachmas ranging from Wahram V (420-438) to Khusro I (531-578). Most of the coins were struck by Kawad I (488-531) and Khusro I. The most common mint abbreviations are AS (Asuristan), AY (Eran-Khwarrah-Shapur), WH (Weh-Andiyok-Shapur), MY (Meshan) and AW (Ohrmazd-Ardashir). A brief discussion of the mint signatures is presented.

\section{AUTHORS}

NIKOLAUS SCHINDEL

Österreichische Akademie der Wissenschaften, Wien 